\title{
Interview with Chantal Wright
}

Clarissa Prado Marini*

Chantal Wright is Associate Professor at the University of Warwick's Department of English and Comparative Literary Studies, where she works at the MA in Literary Translation Studies (MALTS), the MA in Writing (MAW) and the PhD in Translation Studies. She holds a PhD in Literary Translation (University of East Anglia) and her current research themes are theory and practice of literary translation; stylistics; exophonic, migrant and intercultural literature; and the translation of children's and young adult literature. Professor Wright is also a literary and academic translator from German and French into English, having translated Zoran Drvenkar, Cornelia Funke, Milena Baisch, Andreas Steinhöfel, Tzveta Sofronieva, Yoko Tawada and Antoine Berman. She is the coordinator of The Warwick Prize for Women in Translation.

In this interview, Wright comments on her academic path in Translation Studies and the situation of this field within the British context. She then elaborates on her translation practice, focusing especially on her translation of Antoine Berman's L'Âge de la traduction into English - The Age of Translation (2018). Finally, Chantal Wright presents some of her current projects such as the collective translation project of Henri Meschonnic's oeuvre into English as well as the The Warwick Prize for Women in Translation, which she coordinates.

Clarissa Marini: How was the beginning of your career as a translator? And how did your academic path cross the theme of translation? When did those two paths come together?

* Universidade Federal de Santa Catarina (UFSC) 
Chantal Wright: I studied Modern and Medieval Languages at Cambridge. Translation was only a small part of the curriculum there; we had a weekly class for which we would submit a short translation and then we would discuss the text and its challenges together as a group. This was one of my favourite parts of the BA degree, perhaps because it was a such focussed task and dependent on linguistic skill. I then taught English as a Second Language for a few years before returning to academic study at the University of East Anglia in Norwich where the British Centre for Literary Translation is based. I had a feeling that literary translation might be my "thing", and the MA degree at UEA confirmed that feeling. I had a great year there and began sending out translations to publishers almost as soon as I graduated. I also began studying for my $\mathrm{PhD}$ at UEA at about the same time, so my freelance career as a translator and my academic career went hand-in-hand.

\section{CM: What do you think of the relation between translator training, re- search in translation and translation's market?}

CW: I'm going to confine my answer to literary translation, since this is my field of expertise. There is less of a gap between Translation Studies within academia and translation in the real world than there used to be, at least in the British context. The number of "young" literary translators (let's say, under the age of 45) who have studied translation at university is growing, and I think this has reduced scepticism towards the academic study of translation. Universities are also making it part of their mission to support translation in the real world through public engagement activities, summer schools and prizes, and this too has improved relations between ivory tower and "literary coalface". It would be my hope that students who graduate from an MA programme that specialises in literary translation are confident, informed practitioners who are able to defend themselves and their profession in the marketplace.

CM: How do you see Translation Studies in the British academic world today? 
CW: Translation Studies in the British context at MA level have become quite specialised (degrees tend to have a particular focus, e.g. literary translation, AVT, translation and cultural studies, language pair-specific translation etc.). In the UK Translation Studies are still overwhelmingly housed within Modern Languages, although literary translation studies tend to be more closely aligned with creative writing programmes and housed in English/Literary Studies departments, e.g. at the University of Warwick and at the University of East Anglia. In terms of research, many members of a highly influential generation have either retired, substantially reduced their institutional commitments or are approaching retirement - Mona Baker, Susan Bassnett, Jean Boase-Beier, Theo Hermans, Christina Schäffner and Clive Scott, for instance. New professors have been appointed over the past five years - Loredana Polezzi at Cardiff, Michelle Bolduc at Exeter, Duncan Large at UEA and Kathryn Batchelor at UCL - but a new generation of Translation Studies scholars is still establishing itself. Modern Languages in the UK are under threat from falling numbers of school pupils studying languages, and from Brexit and an increasingly xenophobic and insular climate. It remains to be seen what the knock-on effects on Translation Studies will be, although I would say that the state of the literary translation profession in the UK has improved greatly over the past few years.

\section{CM: What do you think about the relation between translation theory and practice?}

CW: If I had a pound for every time an experienced, respected (usually older) literary translator has told me that they find translation theory completely useless, I'd be a rich woman. I concur with Jean Boase-Beier that we all have theories about things, even if they are not explicitly formulated. A statement that translation theory is completely useless is also a sort of theory about how translation works: i.e. spontaneously; that translation is simply something that one is able to do and that one does in a very matter of fact kind of way; that translators and translators are somehow neutral, ahistorical agents. 
But this type of statement may also result from a problem with our understanding of theory as it relates to translation, and a failure to differentiate between theory, method, and philosophy or reflection.

Translation is a practice, a translation is an event, and translators are agents, however much they may wish to deny this fact. Practices, events and agents are all traditionally objects of intellectual enquiry. We can look at translation historically, in sociological terms, as a political act. It is simply naïve to assume that translation is somehow "neutral" and cannot be analysed, and that practice cannot be improved by theorisation, method or reflection.

\section{CM: Which scholars have influenced you the most? And which are the au- thors and titles that you use in class when you teach translation theory?}

CW: I was fortunate enough to be at the University of East Anglia when two major figures in British literary translation studies were teaching there: Jean Boase-Beier and Clive Scott, both of whom supervised my PhD thesis. Both professors are now retired but are intellectually more active than ever and I continue to find their work invaluable. Jean Boase-Beier's work on stylistics and translation, grounded in a cognitive approach to the act of reading, is of great practical use to literary translators as they learn how to read for translation. Clive Scott's work grows out of the creative turn of the 2000s but takes it in a new direction. His recent work is quite left-field and pushes the boundaries of literary translation studies in challenging and exciting ways. Across the Atlantic I find Lawrence Venuti's work incredibly important. It isn't always read properly and is often (and wrongly) reduced to the domesticationforeignisation binary. Translation Changes Everything in particular is a key collection of essays.

In my own classroom, I use The Translation Studies Reader to teach my core MA module on Translation Studies.

CM: You are at first a literary translator, aren't you? What has led you to translate theoretical texts? 
CW: The Berman text was an irresistible challenge. Producing an English translation of a French text written by an eminent French translation theorist and focussing on the most important German essay on translation by one of Germany's greatest thinkers - who wouldn't want to give that a go? And, of course, there is plenty that is literary in theoretical texts, in particular in a text that is as performative as Berman's.

CM: Your translation of Antoine Berman's The Age of Translation into English was published in 2018 (ten years after the publication of the original L'Âge de la traduction. It is a book organized by Isabelle Berman and Valentina Sommella after Antoine Berman's notebooks. On the cover of The Age of Translation we can see at the top of the page the name of the author, or, rather, the names of the authors, since you have placed the names of Antoine Berman, Isabelle Berman and Valentina Sommella together, as the (multiple) authors of the book. This decision intrigued me, could you explain the reasons?

CW: This was actually a contractual condition that Routledge agreed upon with the French publisher, Presses universitaires de Vincennes. But nonetheless I think it's only fair: Isabelle Berman, in collaboration with Valentina Sommella, created L'Âge de la traduction on the basis of Antoine Berman's unedited cahiers. The fact that their names are on the cover acknowledges the work that went into making the text available to us, but it's also a statement about the collaborative nature of authorship.

CM: In your introduction, you comment some translation choices, develop some reflexions on translation (as a process and as a product) and comment some of Berman's and Benjamin's theoretical propositions. We can also see the presence of endnotes in each the chapter, including translator's notes. What is the importance of having explanatory notes written by the translator in theoretical books? 
CW: Prefacing a translation is important for any literary text, and that includes theoretical/philosophical texts. Readers should always know that they are reading translations, translators should be given the space to talk about their work and to explain their approach. Where theoretical texts are concerned, there will inevitably be terminological challenges; signifying networks will be subject to mutation. Translations of theoretical texts will ultimately be used in classrooms and for academic research: the reader, and especially the monolingual reader, needs to appreciate that a translation is just one reading of the source text and that the translator has made certain decisions that will affect the reader's access to and understanding of the text (it is astonishing how many translations are used in classrooms around the world without any such understanding). Translation is also an intellectual endeavour - the translator is a scholar and an expert - and paratexts allow the translator to fully occupy this position.

\section{CM: Why have you written introductions to each chapter?}

CW: The chapter introductions are more than simple summaries of each of Berman's cahiers. They are also an opportunity to highlight the particular challenges of translating the cahier in question, and to comment on the work of thinking between English, French and German. In this sense they extend the work of (linguistic) commentary that is central to Berman's endeavour. There is much more to be said about L'Âge de la Traduction than I have managed to say in the translation's paratexts, but I hope to do this in other fora in the near future.

\section{CM: Can you comment the project of translating Henri Meschonnic's work in which you participate?}

CW: This is a project that was conceived by Marko Pajevic, Professor of German Studies at the University of Tartu, who studied under Meschonnic in Paris. With the notable exception of Pier-Pascale Boulanger's translation Ethics and Politics of Translating (John Benjamins, 2011), Meschonnic's work is 
unavailable in English and his thought is largely unknown in the Anglophone world as a result. Marko Pajevic realised this and obtained British Academy funding to bring together a team of translators with different specialisations to work on Meschonnic's texts. "Team Mescho" comprises Marko, myself, Pier-Pascale, John E. Joseph from Edinburgh, David NowellSmith from UEA and Andrew Eastman from Strasbourg (another of Meschonnic's students). We held two translation workshops at Queen Mary, University of London - one in 2017 and one in early 2018 - during which we tried to establish what our approach would be, discussed terminological issues and so on. We also edited each other's work when our initial translation drafts were complete. It was interesting for me to work with colleagues whose primary expertise lies in linguistics, the philosophy of language and critical theory. The translational accent is very different to that of literary translation, with concerns over terminological consistency paramount.

\section{CM: What is the importance of translating theoretical texts to the develop- ment of a global field of studies dedicated to Translation?}

CW: Pier-Pascale Boulanger and I talked about this during our Meschonnic workshops. Pier-Pascale told me that one of the reasons she was so keen to translate Meschonnic into English was because Anglophone students of translation in Canada were ignorant of the provenance and development of certain schools of thought precisely because important thinkers like Meschonnic remain untranslated. I've noticed the same thing with Antoine Berman - the fact that he died so young and that much of his work has appeared posthumously and hence not in chronological order has delayed and disrupted his reception and therefore also his place in the history of translation thought in the Anglophone domain. Translation Studies is very Eurocentric - I think most scholars agree on that - and within this Eurocentrism national traditions still focus on their own thinkers: Venuti has dominated the Anglophone sphere; Meschonnic, Berman and more recently Cassin have been influential in France; the German-speaking world is still engaged with Vermeer's functionalist tradition, and of course with Goethe, Schleiermacher, Benjamin. Translating translation theory, methodology and philosophy 
is the prerequisite for a more inclusive Translation Studies, and as Translation Studies scholars, I think that we should look at our language pairs and consider how we might help disseminate scholarship from other countries and languages.

CM: Last but - certainly - not least: You are the coordinator of The Warwick Prize for Women in Translation. Could you talk about this project? What is the importance of this prize?

CW: The prize grew out of a grassroots-level concern in the British and Irish literary translation community that fewer female writers were being translated into English than male writers, and that (probably as a consequence) far fewer female writers-in-translation were being nominated for and awarded literary prizes. Warwick has a number of research/public engagement clusters known as "global research priorities" and one of these, Connecting Cultures, took the decision to fund the prize - which has just been awarded for the second time. The hope is that the prize will effect lasting change by persuading publishers to commission more translations of work by female writers and hence redressing the statistical balance. It's early days and the prize is not yet financially secure - we are keen to attract external sponsorship to ensure its continuity - but it is garnering significant media attention. This year's winner, Croatian writer Daša Drndić, who sadly died several months before her novel Belladonna was awarded the 2018 Prize, has attracted quite a lot of media coverage in recent weeks. It's hard to say, of course, to what extent this is the effect of the Prize and its very dedicated judges who do much to promote it, and how much of it is the result of the efforts of Drndić's fantastic publisher, the equally dedicated Maclehose Press, but hopefully the Prize has not been without significance. 